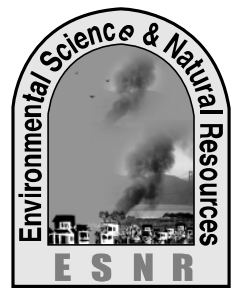

\title{
Comparative Study on Commercial Broiler Rearing Pattern in Plain and Coastal Regions of Bangladesh
}

\author{
M. S. Islam ${ }^{1}$, M. M. Hossain ${ }^{1}$, M. M. Kamal ${ }^{2}$ and M. A. Hashem ${ }^{1}$, \\ ${ }^{1}$ Department of Animal Science, Bangladesh Agricultural University, Mymensingh-2202. \\ ${ }^{2}$ Department of Entomology, Bangladesh Agricultural University, Mymensingh-2202.
}

\begin{abstract}
The study was conducted at Sharsa, Jhikargacha, Chawgacha and Jessore sadar upazila of Jessore District regarded as plain and Lalmohon, Borhanuddin, Daulatkhan and Bhola sadar upazila of Bhola District regarded as coastal region with a view to compare the present status and rearing pattern of broiler. Data were collected randomly from selected 52 broiler farmers through personal interview using an interview schedule. The highest number of broiler farmers $69.2 \%$ and $57.7 \%$ in Jessore and Bhola District, respectively belonged to middle aged group (31-50 years) involved in broiler farming. About $48.1 \%$ and $59.6 \%$ broiler fermers respondents of Jessore and Bhola District, respectively possessed secondary level of education involved in broiler farming. About $48.08 \%$ and $63.46 \%$ broiler farmers in Jessore and Bhola District, respectively disinfected their farm using lime water. About $40.38 \%$ broiler fermers administered vaccine against ranikhet, gumboro, infectious bronchitis diseases and $36.64 \%$ administered vaccine against ranikhet and gumboro diseases in Jessore and Bhola District, respectively. About 36.54\% broiler fermers applied antibiotic against coccidiosis, dermatitis and respiratory infection diseases and $44.23 \%$ broiler fermers applied antibiotic against coccidiosis, dermatitis and respiratory infection diseases in Jessore and Bhola District, respectively. The highest number of broiler farmers in Jessore District faced great marketing problems due to unfavorable market for selling broiler, high price of feed and chick and in Bhola District the farmers faced great marketing problem due to the unstable and high price of feed and chicks.
\end{abstract}

Key Words: Broiler farming, Coastal region, Disease management and Plain region.

\section{Introduction}

Poultry is an integral part of the farming systems and perform a variety of roles, either supplying products for household, for sale or providing inputs for crop production. Among animal population in Bangladesh about 265.7 million poultry is estimated and the number of poultry per rural household is 2.15 respectively (BBS, 2009). Commercial poultry farming system is considered an important venue to reduce unemployment, poverty and malnutrition problem (Ershad et al., 2004). Over the last decade, poultry population has grown spectacularly throughout the world, $23 \%$ in developed and $76 \%$ in developing countries, respectively. This increase, due to the commercial production, has been most notable in the Far East where growth averaged 90\%. However, with increasing population and decreasing land holdings, the number of poultry is increasing at an annual rate of $5.9 \%$ (Huque et al., 1999). 69\% of poultry are reared by small farmers where as $31 \%$ are managed by medium and large farmers. The majority portion of farmers raise $77.29 \%$ chicken and $84.41 \%$ duck, respectively in Bangladesh (Yasmin et al., 1989). About 70,000 different sized poultry farms have been established. Of them $20 \%$ has been rearing 1000-50000 birds and the rests are occupied by smallholders who rear 100-1000 birds (Huque Q.M.E 2001). Average annual broiler meat production was recorded as 9454 kilo broiler meat per farm. The per capita consumption of meat per annum is $5.27 \mathrm{~kg}$ which is much lower than that of world's average of $9.5 \mathrm{Kg}$. of meat (Karim, 2001). Broiler production has become a specialized and speedy business at present time for the small-scale farmers of the country. Short life cycle and requirement of relatively less amount of capital attributed to its popularity to the farmers. Broilers are usually marketed at about 35 to 40 days. Within this short duration special care and attention regarding housing, feeding, prevention and control of diseases can make this business profitable. Commercial broiler farming have provided employment opportunities for unemployed family members, improved socio-economic conditions and increased women empowerment among rural people of Bangladesh. In Bangladesh most of the broiler farmers have no formal training related to broiler farming. Consequently, production performances are low. To enrich the farmers and other concerned with updated knowledge training is needed (Ershad et al., 2004). Several researches have been carried out research on broiler production in different location of Bangladesh. But there is an acute shortage of information regarding the present status and rearing pattern of broiler in plain and coastal region of Bangladesh. That's why; the present study was conducted with the following objectives:

1) To investigate the present status of broiler farm between plain and coastal region

2) To know the management practices of broiler in those areas 


\section{Materials and methods}

The locations of the study area was selected areas of Sharsa, Jhikargacha, Chawgacha and Jessore sadar upazila of Jessore District regarded as plain land and Lalmohon, Borhanuddin, Daulatkhan and Bhola upazila of Bhola District regarded as coastal region. Both districts are situated under the Agro-Ecological Zone (AEZ) of High Ganges River Floodplain and Young Meghna Estuarine Floodplain, respectively (Anonymous, 1988). All the respondents of selected areas having at least 200 or more broilers were selected randomly for the study. Out of broiler farmers, 13 broiler farmers of every upazila were selected that make the total 52 respondents in each district. Data were collected randomly from selected 52 respondents by the researchers themselves through face to face interview by using interview schedule during October 2011 to December 2011. The variables were categorized in some heads e.g. personal information of the respondents (age, educational qualification, training exposure, total annual income from broiler and sources of money), rearing pattern of broiler (strain, sources of chick, housing management, summer management, winter management, litter management, feeding management etc.) and disease management (sources of veterinary service, vaccination and antibiotic application, disinfection and disposal of dead bird ). After completion of interview all the interview schedules were compiled for its data processing. At the beginning of the data processing all the qualitative data were converted into quantitative form. Local units were converted into standard units. The data were coded and tabulated in a data sheet. Then data were entered in statistical software for further analysis. The SPSS 12.0 computer package program was used to analyze the data. All personal traits were categorized and then frequency and percentage of the respondents were calculated.

\section{Results and Discussion}

\section{Personal and socio-economic characteristics of the broiler farmers:}

It was found from the Table 1 that $69.2 \%$ in Jessore and $57.7 \%$ broiler fermers in Bhola district belongs to middle aged group, followed by young aged group $24.1 \%$ and $25.0 \%$ and only $7.7 \%$ and $17.3 \%$ in Jessore and Bhola district, respectively belongs to old aged group involved in broiler farming. It is evident that in Jessore district the middle aged people were more involved in broiler farming as compared to that of Bhola district. The maximum number of broiler farmers both in Jessore and Bhola district, respectively had secondary level of education, followed by higher secondary level $17.3 \%$ and $25 \%$ in Jessore and Bhola district, respectively. Only 11.5\% farmers were illiterate in Jessore district. The majority of the broiler fermers $(44.2 \%$ and $57.7 \%)$ under Jessore and Bhola district, respectively had no training on broiler farming and only lowest number of respondents $(3.8 \%)$ in Jessore district had higher training. The highest percentage of the broiler farmers (76.9\% \& 86.54\%) under Jessore and Bhola district, respectively possessed less number of broilers in their farm while the lowest number of broiler farmers (3.8\% and 1.92\%) in Jessore and Bhola district, respectively had large number of broiler in their farm. It was also found that $46.2 \%$ and $13.5 \%$ broiler farmers under Jessore and Bhola district, respectively earned medium income from broiler. About $17.3 \%$ and $71.2 \%$ broiler farmers in Jessore and Bhola district, respectively earned high income from broiler. Only $36.5 \%$ and $15.4 \%$ broiler farmer in Jessore and Bhola district, respectively earned low income from broiler. It is clear that more than two-third of the respondents incurred with broiler farming in Jessore district earned medium income from broiler and in Bhola district more than half of the broiler producer earned high income from broiler. 
Table : Personal and socio-economic characteristics of the respondents $(n=52)$

\begin{tabular}{|c|c|c|c|c|c|c|c|c|c|c|c|}
\hline \multirow{2}{*}{\multicolumn{2}{|c|}{ Age group (year) }} & \multicolumn{2}{|c|}{ Number } & \multicolumn{2}{|c|}{$\begin{array}{c}\text { Distribution } \\
\text { of the } \\
\text { respondents } \\
(\%)\end{array}$} & \multicolumn{2}{|c|}{ Max } & \multicolumn{2}{|c|}{ Min } & \multicolumn{2}{|c|}{ Mean \pm SD } \\
\hline & & $\begin{array}{c}\text { Jessor } \\
\text { e }\end{array}$ & $\begin{array}{c}\text { Bhol } \\
\mathbf{a}\end{array}$ & $\begin{array}{c}\text { Jessor } \\
\text { e }\end{array}$ & $\begin{array}{c}\text { Bhol } \\
\text { a }\end{array}$ & Jessore & Bhola & $\begin{array}{c}\text { Jessor } \\
\text { e }\end{array}$ & Bhola & Jessore & Bhola \\
\hline Young & $\begin{array}{c}\text { up to } \\
30\end{array}$ & 12 & 13 & 24.1 & 25.0 & \multirow{3}{*}{65} & \multirow{3}{*}{65} & \multirow{3}{*}{25} & \multirow{3}{*}{22} & \multirow{3}{*}{$\begin{array}{c}40.90 \\
\pm 10.86\end{array}$} & \multirow{3}{*}{$\begin{array}{l}43.02 \\
\pm 9.73\end{array}$} \\
\hline Middle & $\begin{array}{c}31- \\
50\end{array}$ & 36 & 30 & 69.2 & 57.7 & & & & & & \\
\hline Old & $>50$ & 4 & 9 & 7.7 & 17.3 & & & & & & \\
\hline \multicolumn{12}{|c|}{ Level of education (year) } \\
\hline Illiterate & 0 & 6 & 0 & 11.5 & 0 & \multirow{5}{*}{18} & \multirow{5}{*}{17} & \multirow{5}{*}{0} & \multirow{5}{*}{5} & \multirow{5}{*}{$\begin{array}{c}8.46 \\
\pm 4.44\end{array}$} & \multirow{5}{*}{$\begin{array}{l}10.81 \\
\pm 2.70\end{array}$} \\
\hline Primary & $1-5$ & 8 & 1 & 15.4 & 1.9 & & & & & & \\
\hline $\begin{array}{l}\text { Secondar } \\
\text { y }\end{array}$ & $6-10$ & 25 & 31 & 48.1 & 59.6 & & & & & & \\
\hline $\begin{array}{l}\text { Higher } \\
\text { secondar } \\
\text { y }\end{array}$ & $11-12$ & 9 & 13 & 17.3 & 25 & & & & & & \\
\hline $\begin{array}{l}\text { Graduate } \\
\text { / } \\
\text { Post } \\
\text { graduatio } \\
\text { n }\end{array}$ & $>12$ & 4 & 7 & 7.7 & 13.5 & & & & & & \\
\hline \multicolumn{12}{|c|}{ Exposure to training (number) } \\
\hline \begin{tabular}{l|} 
No \\
Training \\
\end{tabular} & 0 & 23 & 30 & 44.2 & 57.7 & \multirow{4}{*}{3} & \multirow{4}{*}{2} & \multirow{4}{*}{0} & \multirow{4}{*}{0} & \multirow{4}{*}{$\begin{array}{c}0.71 \\
\pm 0.77\end{array}$} & \multirow{4}{*}{$\begin{array}{c}0.48 \\
\pm 0.64\end{array}$} \\
\hline $\begin{array}{l}\text { Low } \\
\text { Training }\end{array}$ & 1 & 23 & 18 & 44.2 & 34.6 & & & & & & \\
\hline $\begin{array}{l}\text { Medium } \\
\text { Training }\end{array}$ & 2 & 4 & 4 & 7.7 & 7.7 & & & & & & \\
\hline $\begin{array}{l}\text { High } \\
\text { Training }\end{array}$ & $>2$ & 2 & 0 & 3.8 & 0 & & & & & & \\
\hline \multicolumn{12}{|c|}{ Farm size (number of broiler) } \\
\hline Small & $\begin{array}{l}\text { Up to } \\
500\end{array}$ & 40 & 45 & 76.9 & 86.54 & \multirow{3}{*}{10000} & \multirow{3}{*}{4500} & \multirow{3}{*}{200} & \multirow{3}{*}{300} & & \\
\hline Medium & $\begin{array}{l}501- \\
1000\end{array}$ & 10 & 6 & 19.2 & 11.54 & & & & & $\begin{array}{c}817.31 \\
\pm 1678.46\end{array}$ & $\begin{array}{c}1135.58 \pm 861 \\
.62\end{array}$ \\
\hline Large & $>1000$ & 2 & 1 & 3.8 & 1.92 & & & & & & \\
\hline Income fr & m broil & r farmin & (BDT & BDT 83. & $75=1 \$)$ & & & & & & \\
\hline $\begin{array}{l}\text { Low } \\
\text { income }\end{array}$ & $\begin{array}{l}\text { Up to } \\
30000 \\
0\end{array}$ & 19 & 8 & 36.5 & 15.4 & & & & & & \\
\hline $\begin{array}{l}\text { Medium } \\
\text { income }\end{array}$ & $\begin{array}{c}30000 \\
1- \\
50000 \\
0\end{array}$ & 24 & 7 & 46.2 & 13.5 & $\begin{array}{c}360000 \\
0.00\end{array}$ & $\begin{array}{c}3037500 \\
00\end{array}$ & $\begin{array}{c}80000 . \\
00\end{array}$ & $\begin{array}{c}75600 . \\
00\end{array}$ & $\begin{array}{c}47 / 135.5 \\
8 \\
+584223 \\
11\end{array}$ & $\begin{array}{c}814208.65 \\
\pm 556001.14\end{array}$ \\
\hline $\begin{array}{l}\text { High } \\
\text { income }\end{array}$ & $\begin{array}{c}>5000 \\
00\end{array}$ & 9 & 37 & 17.3 & 71.2 & & & & & & \\
\hline
\end{tabular}

\section{Present status of the broiler farmers:}

Table 2 shows that own money and bank loan were the main source of money for $40.38 \%$ and $23.08 \%$ broiler farmers in Jessore and Bhola districts, respectively. Own and NGO's loan were also another important source of money for $32.69 \%$ and $15.38 \%$ broiler farmers in Jessore and Bhola districts, respectively. Only $5.77 \%$ and $13.31 \%$ broiler farmers 
in Jessore and Bhola districts, respectively used NGO's loan to start broiler farming.

Table 2 also showed that more than half of the broiler farmers in Jessore and Bhola districts, respectively started their farm with Cov-500 broiler strain. The majority of broiler farmers $(55.77 \%$ and $67.31 \%)$ in Jessore and Bhola districts, respectively bought chicks from Aftab Bohumukhi Farms Ltd. About
$17.31 \%$ and $7.69 \%$ broiler farmers in Jessore and Bhola districts, respectively collected day old chick from Kazi Poultry Farms Ltd. Only $11.54 \%$ farmers collected chicks from Pragon Poultry Farms Ltd. in Bhola districts. It is clear that most of the respondents bought chicks from Aftab Bohumukhi Farms Ltd. due to their better quality of chicks.

Table 2: Categories of the respondents on the basis of sources of money and broiler stain $(n=52)$

\begin{tabular}{|c|c|c|c|c|}
\hline \multirow{3}{*}{ Source of money } & \multicolumn{4}{|c|}{ Citation number } \\
\hline & \multicolumn{2}{|c|}{ Number } & \multicolumn{2}{|c|}{$\begin{array}{c}\text { Distribution of the } \\
\text { respondents }(\%)\end{array}$} \\
\hline & Jessore & Bhola & Jessore & Bhola \\
\hline Own & 5 & 3 & 9.62 & 5.77 \\
\hline Bank loan & 2 & 0 & 3.85 & 0 \\
\hline NGO loan & 3 & 9 & 5.77 & 13.31 \\
\hline Job & 0 & 3 & 0 & 5.77 \\
\hline Own + bank loan & 21 & 12 & 40.38 & 23.08 \\
\hline Own + NGO loan & 17 & 8 & 32.69 & 15.38 \\
\hline Own + Job & 0 & 2 & 0 & 3.85 \\
\hline Bank loan + NGO loan & 1 & 2 & 1.92 & 3.85 \\
\hline NGO loan + Others & 2 & 2 & 3.85 & 3.85 \\
\hline Bank loan + Job & 0 & 2 & 0 & 3.85 \\
\hline Own + Bank loan +Job & 0 & 3 & 0 & 5.77 \\
\hline Own +NGO loan +Job & 0 & 2 & 0 & 3.85 \\
\hline Own + Others & 1 & 1 & 1.92 & 1.92 \\
\hline Own + NGO loan + Others & 0 & 3 & 0 & 5.77 \\
\hline \multicolumn{5}{|l|}{ Name of the strain reared } \\
\hline Cov-500 & 27 & 30 & 51.52 & 57.69 \\
\hline Lohman meat & 1 & 0 & 1.92 & 0 \\
\hline Habbard classic & 19 & 13 & 36.54 & 25 \\
\hline Others & 5 & 9 & 9.62 & 17.31 \\
\hline \multicolumn{5}{|c|}{ Name of the hatcheries supplied } \\
\hline Aftab Bohumukhi Farms Ltd. & 29 & 35 & 55.77 & 67.31 \\
\hline Kazi Poultry Farm Ltd. & 9 & 4 & 17.31 & 7.69 \\
\hline Afil Agro Ltd. & 7 & 0 & 13.46 & 0 \\
\hline Nourish Poultry Farm & 3 & 4 & 5.77 & 7.69 \\
\hline Pragon Poultry Farm Ltd. & 0 & 6 & 0 & 11.54 \\
\hline Others & 4 & 3 & 7.69 & 5.77 \\
\hline
\end{tabular}

NB : NGO, Non-government organization.

\section{Special managemental precaution of the broiler farmers:}

Table 3 shows that the majority of the respondents $(44.23 \%$ and $55.77 \%)$ reduced ambient temperature using electric fan, supply of saline water and maintaining proper ventilation while $25 \%$ and $13.46 \%$ broiler farmers in Jessore and Bhola districts, respectively used electric fan and proper ventilation. Only $17.31 \%$ and $13.46 \%$ farmers in Jessore and Bhola districts, respectively used electric fan and saline water to reduce ambient temperature during summer in broiler farm. Majority of the broiler farmers $(75 \%$ and $76.92 \%)$ in Jessore and Bhola districts, respectively increased ambient temperature during winter season using curtain and light. The highest number of broiler farmers $(28.85 \%)$ kept their farm 15 days interval before starting another batch and $30.77 \%$ broiler farmers kept their farm 5 days interval in Jessore and in Bhola districts, respectively. Only $1.92 \%$ of broiler farmers kept interval their farm from rearing for 30 days before starting another batch in Jessore. 
Table 3: Distribution of the respondents on the basis of special managerial precaution $(n=52)$.

\begin{tabular}{|c|c|c|c|c|}
\hline \multirow[t]{3}{*}{ Management during summer season } & \multicolumn{4}{|c|}{ Citation Number } \\
\hline & \multicolumn{2}{|c|}{ Number } & \multicolumn{2}{|c|}{$\begin{array}{l}\text { Distribution of the } \\
\text { respondents }(\%)\end{array}$} \\
\hline & Jessore & Bhola & Jessore & Bhola \\
\hline \multicolumn{5}{|l|}{ Means for reducing ambient temperature } \\
\hline Electric fan & 3 & 5 & 5.77 & 9.62 \\
\hline Proper ventilation & 1 & 2 & 1.92 & 3.85 \\
\hline Electric fan + ventilation & 13 & 7 & 25.0 & 13.46 \\
\hline Electric fan + Drinking of saline water & 9 & 7 & 17.31 & 13.46 \\
\hline Electric fan + Drinking of saline water + ventilation & 23 & 29 & 44.23 & 55.77 \\
\hline Others & 3 & 2 & 5.77 & 3.85 \\
\hline \multicolumn{5}{|l|}{ Management during winter season } \\
\hline \multicolumn{5}{|l|}{ Means for improving ambient temperature } \\
\hline Curtain & 1 & 2 & 1.92 & 3.85 \\
\hline Light & 11 & 9 & 21.15 & 17.31 \\
\hline Curtain + light & 39 & 40 & 75.0 & 76.92 \\
\hline Others & 1 & 1 & 1.92 & 1.92 \\
\hline \multicolumn{5}{|l|}{ Interval between two batches (days) } \\
\hline 5 & 10 & 16 & 19.23 & 30.77 \\
\hline 7 & 7 & 2 & 13.46 & 3.85 \\
\hline 9 & 3 & 10 & 5.77 & 19.23 \\
\hline 12 & 9 & 7 & 17.31 & 13.46 \\
\hline 15 & 15 & 11 & 28.85 & 21.15 \\
\hline 18 & 2 & 1 & 3.85 & 1.92 \\
\hline 20 & 3 & 1 & 5.77 & 1.92 \\
\hline 25 & 2 & 4 & 3.85 & 7.69 \\
\hline 30 & 1 & 0 & 1.92 & 0 \\
\hline
\end{tabular}

\section{Feeding management and performance of the broiler:}

Table 4 shows that majority of the broiler farmers both in Jessore and Bhola districts, fed their chicks Vit-C after receiving. About $13.46 \%$ and $25 \%$ broiler farmers in Jessore and Bhola districts, respectively fed their chicks glucose. $21.15 \%$ and $1.92 \%$ farmers fed their broiler cost @BDT 27 / kg of feed while only $1.92 \%$ farmers fed their broilers cost @ BDT $30 / \mathrm{kg}$ of feed in Jessore and Bhola districts, respectively. About $40.38 \%$ and $36.54 \%$ of broiler farmers in Jessore and Bhola districts, respectively reared broiler for 35 days while only $1.92 \%$ in Bhola district, respectively reared their broiler for 43 days. Most of the respondents under Bhola district reared broiler for short duration as compare to that of Jessore district. Table 4 also shows that broiler attained 280 $\mathrm{g} /$ week body weight in the farm of $40.38 \%$ and $21.15 \%$ farmers in Jessore and Bhola districts, respectively. Only $13.46 \%$ and $30.77 \%$ broiler farmers in Jessore and Bhola districts, respectively told that broiler gained body weight $270 \mathrm{~g} /$ week. 
Table 4: Distribution of the respondents on the basis of feeding management and broiler performance $(n=52)$

\begin{tabular}{|c|c|c|c|c|}
\hline \multirow{3}{*}{ Feeding management of chick after arrival } & \multicolumn{4}{|c|}{ Citation Number } \\
\hline & \multicolumn{2}{|c|}{ Number } & \multicolumn{2}{|c|}{$\begin{array}{l}\text { Distribution of the } \\
\text { respondents }(\%)\end{array}$} \\
\hline & Jessore & Bhola & Jessore & Bhola \\
\hline Vitamin-C & 31 & 27 & 59.62 & 51.92 \\
\hline Glucose & 7 & 13 & 13.46 & 25.0 \\
\hline Glucovate & 1 & 2 & 1.92 & 3.85 \\
\hline Saline & 11 & 9 & 21.15 & 17.31 \\
\hline Others & 2 & 1 & 3.85 & 1.92 \\
\hline \multicolumn{5}{|c|}{ Grower and finisher feed price (average price in BDT, BDT $83.75=1 \$$ )) } \\
\hline 24.5 & 7 & 7 & 13.46 & 13.46 \\
\hline 25 & 4 & 5 & 7.69 & 9.62 \\
\hline 25.5 & 7 & 7 & 13.46 & 13.46 \\
\hline 26 & 3 & 7 & 5.77 & 13.46 \\
\hline 26.5 & 14 & 5 & 26.92 & 9.62 \\
\hline 27 & 11 & 12 & 21.15 & 23.08 \\
\hline 27.5 & 1 & 3 & 1.92 & 5.77 \\
\hline 28 & 2 & 2 & 3.85 & 3.85 \\
\hline 28.5 & 2 & 1 & 3.85 & 1.92 \\
\hline 30 & 1 & 1 & 1.92 & 1.92 \\
\hline 31 & 0 & 2 & 0 & 3.85 \\
\hline \multicolumn{5}{|l|}{ Duration of rearing (days) } \\
\hline 35 & 21 & 19 & 40.38 & 36.54 \\
\hline 36 & 5 & 9 & 9.62 & 17.31 \\
\hline 37 & 7 & 5 & 13.46 & 9.62 \\
\hline 38 & 1 & 3 & 1.92 & 5.77 \\
\hline 39 & 5 & 5 & 9.62 & 9.62 \\
\hline 40 & 1 & 1 & 1.92 & 1.92 \\
\hline 41 & 2 & 1 & 3.85 & 1.92 \\
\hline 42 & 7 & 9 & 13.46 & 17.31 \\
\hline 43 & 0 & 1 & 0 & 1.92 \\
\hline 44 & 1 & 1 & 1.92 & 1.92 \\
\hline 45 & 2 & 0 & 3.85 & 0 \\
\hline \multicolumn{5}{|l|}{ Body weight gain /week (g) } \\
\hline 250 & 3 & 1 & 5.77 & 1.92 \\
\hline 260 & 5 & 9 & 9.62 & 17.31 \\
\hline 270 & 7 & 16 & 13.46 & 30.77 \\
\hline 280 & 21 & 11 & 40.38 & 21.15 \\
\hline 290 & 1 & 5 & 1.92 & 9.62 \\
\hline 300 & 7 & 5 & 13.46 & 9.62 \\
\hline 310 & 8 & 5 & 15.38 & 9.62 \\
\hline
\end{tabular}

\section{Disease Management of Broiler:}

Table 5 shows that most of the broiler farmers (36.54\%) used own veterinary knowledge for disease combat in Jessore and $28.85 \%$ farmers in Bhola district got veterinary service from NGOs. About $25 \%$ and $13.46 \%$ broiler farmers in Jessore and Bhola district, respectively got veterinary service from private practitioner. Most of the broiler farmers (48.08\% and $63.46 \%$ ) disinfected their farm by using lime water while $17.31 \%$ and $1.92 \%$ broiler farmers in Jessore and Bhola district, respectively disinfected farm using Lysol disinfectant. About $40.38 \%$ farmers administered vaccine against Ranikhet, Gumboro and Infectious Bronchitis diseases and 36.64\% farmers administered vaccine against Ranikhet and Gumboro diseases in Jessore and Bhola district, respectively. Only 25\% farmers administered vaccine against Ranikhet, Gumboro, Marek's and Infectious Bronchitis diseases in Jessore and 28.85\% farmers administered vaccine against Ranikhet, Gumboro and Infectious Bronchitis diseases in Bhola districts. Majority of the farmers in Jessore and Bhola districts, respectively administered antibiotic against Coccidiosis, Dermatitis and Respiratory infection diseases. About $28.85 \%$ and $25.0 \%$ of the farmers in Jessore and Bhola district, respectively administered antibiotic against Coccidiosis, Dermatitis, Respiratory infection and Wingrot diseases. It is clear that most of the farmers in Jessore district applied antibiotic against Coccidiosis, Dermatitis and Respiratory 
infection diseases while in Bhola, most of the farmers applied antibiotic against Coccidiosis, Dermatitis, Respiratory infection and Wingrot diseases. The occurrence of diseases varies due to geographical variation.

Table 5: Categories of the respondents on the basis of diseases management $(n=52)$

\begin{tabular}{|c|c|c|c|c|c|}
\hline \multirow{3}{*}{\multicolumn{2}{|c|}{ Source of Veterinary Service }} & \multicolumn{4}{|c|}{ Citation Number } \\
\hline & & \multicolumn{2}{|c|}{ Number } & \multicolumn{2}{|c|}{$\begin{array}{c}\text { Distribution of the } \\
\text { respondents }(\%)\end{array}$} \\
\hline & & Jessore & Bhola & \multirow{2}{*}{$\frac{\text { Jessore }}{36.54}$} & \multirow{2}{*}{$\frac{\text { Bhola }}{5.77}$} \\
\hline Own veterinary knowledge & & 19 & 6 & & \\
\hline Government veterinary doctor & & 0 & 6 & 0 & 11.54 \\
\hline Private practitioner & & 13 & 7 & 25.0 & 13.46 \\
\hline Veterinary doctor from NGOs & & 4 & 15 & 7.69 & 28.85 \\
\hline Veterinary doctor from NGOs + Private practitioner & & 3 & 2 & 5.77 & 3.85 \\
\hline $\begin{array}{l}\text { Veterinary doctor from NGOs + Government veterinary } \\
\text { doctor }+ \text { Own veterinary knowledge }\end{array}$ & & 1 & 3 & 1.92 & 5.77 \\
\hline $\begin{array}{l}\text { Veterinary doctor from NGOs + Government veterinary } \\
\text { doctor }\end{array}$ & & 1 & 7 & 1.92 & 13.46 \\
\hline $\begin{array}{l}\text { Own veterinary knowledge }+ \text { Veterinary doctor from } \\
\text { NGOs }\end{array}$ & & 4 & 2 & 7.69 & 3.85 \\
\hline Own veterinary knowledge +Private Practitioner & & 2 & 2 & 3.85 & 3.85 \\
\hline $\begin{array}{l}\text { Own veterinary knowledge + Veterinary doctor from } \\
\text { NGOs + Private Practitioner }\end{array}$ & & 5 & 1 & 9.62 & 1.92 \\
\hline \multicolumn{6}{|c|}{ Disinfection of farm after rearing one batch (disinfectant used) } \\
\hline QAC & 3 & & 0 & 5.77 & 0 \\
\hline Lysol & 9 & & 1 & 17.31 & 1.92 \\
\hline Lime water & 25 & & 33 & 48.08 & 63.46 \\
\hline Vircon & 7 & & 2 & 13.46 & 3.85 \\
\hline Lime water + Bleaching powder & 2 & & 12 & 3.85 & 23.08 \\
\hline Others & 6 & & 4 & 11.54 & 7.69 \\
\hline \multicolumn{6}{|l|}{ Vaccination used for the diseases } \\
\hline Ranikhet diseases & 5 & & 3 & 9.62 & 5.77 \\
\hline Gumboro + Marek's diseases & 1 & & 4 & 1.92 & 7.69 \\
\hline Ranikhet + Gumboro diseases & 5 & & 19 & 9.62 & 36.64 \\
\hline Ranikhet + Gumbor+ Marek's diseases & 6 & & 3 & 11.54 & 5.77 \\
\hline Ranikhet + Gumboro + Infectious Bronchitis & 21 & & 15 & 40.38 & 28.85 \\
\hline $\begin{array}{l}\text { Ranikhet + Gumboro+ Marek's + Infectious Bronchitis } \\
\text { diseases }\end{array}$ & 13 & & 8 & 25.0 & 15.38 \\
\hline Others & 1 & & 0 & 1.92 & 0 \\
\hline \multicolumn{6}{|l|}{ Antibiotics used for the diseases } \\
\hline \multicolumn{6}{|l|}{ Name of the Disease } \\
\hline Coccidiosis + Dermatitis & 3 & & 1 & 5.77 & 1.92 \\
\hline Coccidiosis + Dermatitis+ CRD & 5 & & 6 & 9.62 & 13.46 \\
\hline Coccidiosis + Dermatitis+Pullorum & 3 & & 3 & 5.77 & 9.62 \\
\hline Coccidiosis + Dermatitis + Respiratory infection & 19 & & 23 & 36.54 & 44.23 \\
\hline $\begin{array}{l}\text { Coccidiosis +Dermatitis + Respiratory infection+ Fowl } \\
\text { coryza }\end{array}$ & 1 & & 3 & 1.92 & 5.77 \\
\hline $\begin{array}{l}\text { Coccidiosis + Dermatitis + Respiratory infection + } \\
\text { Wingrot }\end{array}$ & 15 & & 13 & 28.85 & 25.0 \\
\hline Dermatitis + CRD + Respiratory infection & 2 & & 1 & 3.85 & 1.92 \\
\hline Dermatitis +Pullorum +CRD+ Respiratory infection & 3 & & 1 & 5.77 & 1.92 \\
\hline Others & 1 & & 1 & 1.92 & 1.92 \\
\hline
\end{tabular}

\section{Litter management of the broiler farmers:}

Table 6 shows that majority of the broiler farmers $(55.77 \%$ and $63.46 \%)$ used rice husk as litter material on floor while only $3.85 \%$ and $0 \%$ respondents in Jessore and Bhola districts, respectively used chopped straw. It was found that most of the broiler farmers treated litter materials in sun light while only $5.77 \%$ and $1.92 \%$ farmers in Jessore and Bhola districts, respectively treated litter using heat. Majority of the 
broiler farmers $(92.31 \%$ and $98.08 \%)$ used litter $1-4$ inch height on the floor while $7.69 \%$ and $1.92 \%$ farmers in Jessore and Bhola districts, respectively used litter 5-9 inch height. About $75 \%$ and $94.23 \%$ broiler farmers in Jessore and Bhola districts, respectively suggested that litter got wetted with droppings and water. Only $7.69 \%$ and $1.92 \%$ broiler farmers in Jessore and Bhola districts, respectively suggested that litter got wetted from others sources. Most of the broiler farmers $(40.39 \%$ and $30.77 \%)$ in
Jessore and Bhola districts, respectively treated their wet litter with $\mathrm{Ca}(\mathrm{OH})_{2}$ for removing of moisture. About $21.15 \%$ broiler farmers in Jessore treated litter with powder like materials. It is clear that the highest number of broiler farmers in Jessore and Bhola districts treated their wet litter materials with $\mathrm{Ca}(\mathrm{OH})_{2}$. About $5.77 \%$ and $32.69 \%$ broiler farmers disposed the spent litter materials as manure. While $34.62 \%$ and $36.54 \%$ in Jessore and Bhola districts, respectively disposed as fish feed.

Table 6: Categories of broiler farmers on the basis of litter materials $(n=52)$

\begin{tabular}{|c|c|c|c|c|}
\hline \multirow[t]{3}{*}{ Name of the litter materials used } & \multicolumn{4}{|c|}{ Citation Number } \\
\hline & \multicolumn{2}{|c|}{ Number } & \multicolumn{2}{|c|}{$\begin{array}{c}\text { Distribution of the } \\
\text { respondents }(\%)\end{array}$} \\
\hline & Jessore & Bhola & Jessore & Bhola \\
\hline Saw dust & 21 & 15 & 40.38 & 28.85 \\
\hline Rice husk & 29 & 33 & 55.77 & 63.46 \\
\hline Chapped straw & 2 & 0 & 3.85 & 0 \\
\hline Others (Rice polish) & 0 & 4 & 0 & 7.69 \\
\hline \multicolumn{5}{|l|}{ Treatment of litter before using } \\
\hline Sun drying & 39 & 43 & 65.38 & 82.69 \\
\hline Heat treatment & 3 & 1 & 5.77 & 1.92 \\
\hline Chemical treatment & 9 & 7 & 17.31 & 13.46 \\
\hline Others & 1 & 1 & 1.92 & 1.92 \\
\hline \multicolumn{5}{|l|}{ Height of the litter on the floor (inch) } \\
\hline $1-4$ & 48 & 51 & 92.31 & 98.08 \\
\hline $5-8$ & 4 & 1 & 7.69 & 1.92 \\
\hline $9-15$ & 0 & 0 & 0 & 0 \\
\hline \multicolumn{5}{|l|}{ Source of litter get wetted } \\
\hline Droppings & 9 & 2 & 17.31 & 3.85 \\
\hline Droppings + Water & 39 & 49 & 75.0 & 94.23 \\
\hline Others & 4 & 1 & 7.69 & 1.92 \\
\hline \multicolumn{5}{|l|}{ Method of treatment of wetted litter } \\
\hline $\mathrm{Ca}(\mathrm{OH})_{2}$ & 21 & 31 & 40.39 & 30.77 \\
\hline Powder materials & 11 & 0 & 21.15 & 0 \\
\hline Change & 15 & 16 & 28.85 & 59.62 \\
\hline Others & 5 & 5 & 9.62 & 9.62 \\
\hline \multicolumn{5}{|l|}{ Uses of spent litter } \\
\hline Manure & 4 & 17 & 5.77 & 32.69 \\
\hline Fuel & 1 & 1 & 1.92 & 1.92 \\
\hline Fish feed & 17 & 19 & 34.62 & 36.54 \\
\hline Manure+ Fish feed & 27 & 14 & 51.92 & 26.92 \\
\hline Others & 3 & 1 & 5.77 & 1.92 \\
\hline
\end{tabular}

\section{Problem faced for marketing:}

Table 7 shows that about half of the broiler farmers faced great marketing problems due to unfavorable market for selling broiler and high price of feed and chick in Jessore district and $38.46 \%$ faced great marketing problems due to the price of feed and chick are not fixed; high price of feed and chick in Bhola districts. 
Table 7: Categories of the respondents on the basis of marketing problems $(\mathrm{n}=52)$

\begin{tabular}{|c|c|c|c|c|}
\hline \multirow{3}{*}{ Problems faced for marketing } & \multicolumn{4}{|c|}{ Citation number } \\
\hline & \multicolumn{2}{|c|}{ Number } & \multicolumn{2}{|c|}{$\begin{array}{l}\text { Distribution of the } \\
\text { respondents }(\%)\end{array}$} \\
\hline & Jessore & Bhola & Jessore & Bhola \\
\hline Price of feed and chick are not fixed & 1 & 4 & 1.92 & 7.69 \\
\hline High price of feed and chick & 6 & 2 & 11.54 & 3.85 \\
\hline Unfavorable market for selling broiler & 5 & 0 & 9.62 & 0 \\
\hline $\begin{array}{l}\text { Price of feed and chick are not fixed } \\
+ \text { High price of feed and chick }\end{array}$ & 3 & 20 & 5.77 & 38.46 \\
\hline $\begin{array}{l}\text { Unfavorable market for selling broiler } \\
+ \text { High price of feed and chick }\end{array}$ & 25 & 5 & 48.08 & 9.62 \\
\hline $\begin{array}{l}\text { High price of feed and chick } \\
+ \text { Unfavorable market for selling broiler }\end{array}$ & 4 & 4 & 7.69 & 7.69 \\
\hline $\begin{array}{l}\text { The price of feed and chick are not fixed } \\
+ \text { High price of feed and chick } \\
+ \text { Unfavorable market for selling broiler }\end{array}$ & 2 & 10 & 3.85 & 19.23 \\
\hline Others & 6 & 7 & 11.54 & 13.46 \\
\hline
\end{tabular}

\section{Conclusion}

In both districts the middle aged group and farmers of secondary level education were highly involved with broiler farming. Most of the broiler farmers in Bhola district were belonged to high income group as compared to Jessore district. About $51.52 \%$ farmers brought "Cov-500 strains" and $36.54 \%$ brought "Habbard classic" in Jessore and Bhola district respectively. More than half of the broiler farmers in Jessore and Bhola district, respectively treated litter materials in sun light. The most appropriate treating way of wet litter materials were using $\mathrm{Ca}(\mathrm{OH})_{2}$ in Jessore and Bhola district. About $48.08 \%$ and $63.46 \%$ in Jessore and Bhola district, respectively disinfected their farm by using lime water. About $36.54 \%$ and $44.23 \%$ in Jessore and Bhola district respectively applied antibiotic against Coccidiosis, Dermatitis and Respiratory infection diseases. Further in depth study is needed to explore more information related to comparison of broiler production aspects in plain and coastal belt of Bangladesh.

\section{References}

Anonymous. 1988. Agroecological Region of Bangladesh, Report 2, Land Resources Appraisal of Bangladesh for Agricultural Development. United Nations Development Programme, Food and Agricultural Organization of the United Nations, Rome, pp: 570.

BBS, 2009. Census of Agriculture 2006. Structure of Agricultural Holdings and livestock Population, Bangladesh Bureau of Statistics, Government of the People's Republic of Bangladesh, Dhaka, Bangladesh.

Ershad, S. M. E.; Islam, S. S.; Mondal, S. C. and Sarkar, B. 2004. Efficiency of trained farmers on the productivity of broilers in a selected area of Bangladesh. International Journal of Poultry Science., 3 (8): 503-506.

FAO, 1997. Guidelines for the inclusion of improved household poultry production, Special Programme for Food Security, May 1997, pp: 13-14.

Hasan M. M., and Hasan, M. A. H. 2003. Poultry research in Bangladesh: present status, development strategies in the past and in the future. Bangladesh Livestock Research Institute, Savar, Dhaka, Bangladesh.

Huque, Q. M. E. and Paul, D. C. 2001. Strategies for Family Poultry with Special Reference to Women Participation. Paper Presented In 1st SAARC Poultry Conference. Held on 24-26, September, 2001. At Pune, India.

Huque, Q. M. E.; Chowdhury, S. A. and Haque M. E. 1999. Poultry research in Bangladesh: present status and its implication for future research. Bangladesh Livestock Research Institute, Savar, Dhaka, Bangladesh.

Karim, Z. 2001. Proceedings of 2nd International seminar organized by WPSA BB held in Dhaka in 2001.

Yasmin, L., Hussain, M. A. and Miah, M. 1989. Characteristics of backyard poultry farmers affecting their knowledge on poultry production. Bangladesh Journal of Training and Development., 2 (1): 22-30. 